\title{
PEMETAAN STRUKTUR SITUS COT SIDI ABDULLAH PENINGGALAN KERAJAAN SAMUDERA PASAI BERDASARKAN SEBARAN MODEL RESISTIVITAS
}

\author{
Agus Hari Pramana ${ }^{1}$, Faisal Abdullah ${ }^{1,2}$, Tomi Afrizal ${ }^{3}$, Nazli Ismail1,2 \\ 1Program Studi Magister Fisika, Universitas Syiah Kuala \\ 2Program Studi Teknik Geofisika, Universitas Syiah Kuala \\ Jl. Teuku Nyak Arief, Darussalam, Banda Aceh, 23111, Indonesia \\ ${ }^{3}$ Earth System Science, Prince of Songkla University \\ Phuket Campus, Phuket, 83120, Thailand \\ e-mail: nazli.ismail@unsyiah.ac.id
}

Diterima: 21 Februari 2020, Direvisi: 09 April 2020, Disetujui: 02 Juni 2020

\begin{abstract}
Abstrak
Metode DC-Resistivity konfigurasi Wenner telah diaplikasikan pada situs cagar budaya Cot Sidi Abdullah (CSA) di Desa Kuta Krueng, Kecamatan Samudra Pasai, Kabupaten Aceh Utara. Data geolistrik diukur pada 8 lintasan sejajar dengan spasi lintasan 5 meter dari arah utara - selatan sepanjang situs dan spasi elektroda 0,5 meter. Berdasarkan hasil model penampang 2D diperoleh zona yang bersifat konduktif dengan kisaran nilai resistivitas 0,1 - 80 $\Omega m$ dan zona resistif dengan nilai reistivitas berkisar antara $100-600$ $\Omega m$ dengan ketebalan lapisan 1 meter. Keberadaan zona yang relatifkonduktif disebabkan oleh adanya intrusi air asin yang terdapat disekeliling daerah itu, yaitu area tambak dan sungai. Sedangkan zona resistif terdapat secara merata di semua lintasan yang umumnya berada di tengah-tengah lintasan dan dapat diprediksikan sebagai bagian dari situs yang tertimbun dibawah permukaan. Zona resistif berupa batu bata yang berada di sekeliling situs dan menahan intrusi air asin masuk ke tengah. Oleh karena itu bangunan Situs CSA diprediksi memiliki luasan sekitar $26 m \times 35$ m dengan bangunan sekeliling berupa batu bata dengan ketebalan dinding situs 1,5 meter. Sedangkan bagian tengah adalah timbunan pasir yang tidak dipengaruhi oleh air asin.
\end{abstract}

Kata kunci: Metode geofisika, Arkeologi, Cot Sidi Abdullah, Metode DC - Resistivity, Resolusi Model, Rekontruksi

\begin{abstract}
The DC-Resistivity method with Wenner configurations was applied to the cultural heritages of Cot Sidi Abdullah (CSA) in Kuta Krueng Village, Samudra Pasai District, North Aceh Regency. Resistivity data were measured on 8 parallel lines with 5 meterline spacing from north to south of the sites and 0.5 meter electrode spacing. The $2 D$ model results show that there are conductive region with the value of resistivity from 0.1-80 $\Omega \mathrm{m}$ and resistive region with resistivity values ranging from $100-600$ with a thickness of 1 meter. The existence of the relatively conductive region is caused by the sea water intrusions which is found surrounding the area, such as fish and river areas. However the resistive region is evenly found in all of the lines which are generally located in the middle of line and it was predicted as a part of Cot Sidi Abdullah site buried under the surface. The resistive region is consist of brick wall structures which surrounding the site can hold the sea water intrusions into the center of the sites. Therefore it can be concluded that the CSA Site has $26 m \times 35 \mathrm{~m}$ areas which is surrounded by the brick structures with 1.5
\end{abstract}


meters thick. Howeverthe middle part of the site is filled with a sand material that is not affected by salt water.

\section{Key words: Geophysics Method, Archaeology, Cot Sidi Abdullah, DC- Resistivity Method, Model Resolution, Reconstruction}

\section{PENDAHULUAN}

Aceh merupakan salah satu provinsi di Indonesia yang memiliki banyak warisan seni budaya peninggalan sejarah berupa bangunan, naskah-naskah kuno, dan jenisjenis budaya lainnya yang bernilai tinggi (Sumarsih, 1985). Bukti peniggalan sejarah seni budaya Aceh berupa situs kerajaan yang tersebar hampir di seluruh wilayah Aceh, salah satunya di kabupaten Aceh Utara.

Kabupaten Aceh Utara merupakan wilayah utara Aceh yang berbatasan langsung dengan Selat Malaka untuk wilayah utara, dan lereng pengunungan untuk wilayah selatan. Secara umum, geomorfologi (Gambar 1) Kabupaten Aceh Utara dari arah pantai ke arah pengunungan terdiri dari dataran pantai yang terletak sepanjang pesisir pantai, dataran aluvial yang terletak memanjang di belakang dataran pantai, yang selanjutnya diikuti oleh zona lipatan, dan zona vulkanik yang merupakan pengunungan (RPJM AU Tahun 2017-2022). Pada kawasan dengan kondisi geologi demikian pernah berdiri sebuah kerajaan Islam megah yang dikenal dengan nama Kerajaan Samudera Pasai.

Kerajaan Samudera Pasai (Pasai) merupakan kerajaan islam pertama di Nusantara (Moquette, 1913) yang berada di pesisir pantai kabupaten Aceh Utara. Saat ini, bukti peninggalan sejarah (arkeologis) dari kerajaan Pasai yang di temukan telah banyak yang rusak, hancur dan tidak utuh. Sebagian besar situs-situs arkeologis peninggalan kerjaan Samudera Pasai telah tertimbun oleh endapan di bawah permukaan (BPCB Aceh, 2014). Situs CSA merupakan salah satu situs sejarah peninggalan dari Kerajaan Samudera Pasai. Situs CSA berada di Desa Kuta Krueng, Kecamatan Samudera, Kabupaten Aceh Utara, Provinsi Aceh.

Ditinjau dari peta geologi Bennet (1981), keadaan geologi daerah penelitian didominasi oleh aluvium muda (Gambar 1). Di sebelah barat daya dari lokasi penelitian terdapat formasi Idi (berwarna merah muda pada peta) dan formasi Julu Rayeu (berwarna hijau sedikit lebih terang pada peta). Pada daerah ini juga terdapat sesar dan sungai seperti yang terlihat pada Gambar 1. Situs CSA saat ini telah tertimbun oleh endapan secara keseluruhan di bawah permukaan. Sehingga perlu dilakukan pelestarian keberadaan situs.

Pelestarian dan penyelamatan situs cagar budaya CSA sangat perlu dilakukan karena keberadaan situs cagar budaya banyak menyimpan sejarah besar. Kajian arkeologi biasanya menggunakan metode ekskavasi (penggalian) seperti yang telah dilakukan oleh BPCB Aceh pada situs CSA pada tahun 2017 (https://kebudayaan kemdikbud.go.id/bpcbaceh/makam-kunodi-bawah-runtuhan-struktur-cot-sidiabdullah). Metode ini akan menjadi sia-sia tanpa adanya informasi awal. Selain itu, metode ini juga memaparkan keberadaan situs itu sendiri secara terbuka seperti Gambar 2, sehingga dapat menyebabkan kerusakan situs arkeologi itu sendiri dan juga dapat mengakibatkan kerusakan benda-benda yang terkubur di bawah permukaan. Oleh sebab itu, perlu digunakan kajian arkeologi dengan metode yang berbeda yang tidak menyebabkan terjadinya kerusakan pada situs arkeologi yang dikaji. 


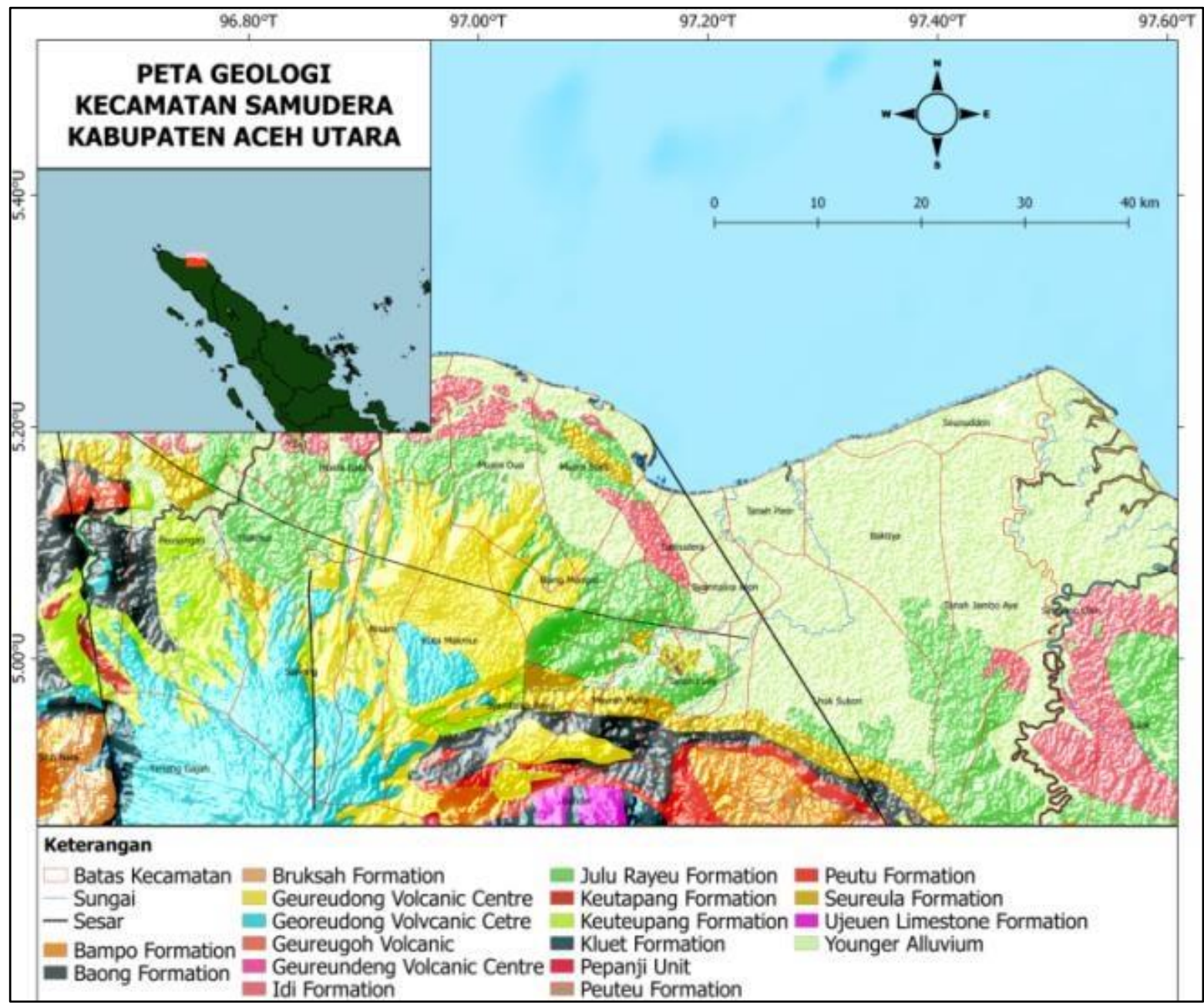

Gambar 1. Peta geologi Kabupaten Aceh Utara

(Sumber: dimodifikasi dari peta Bennet, 1981).

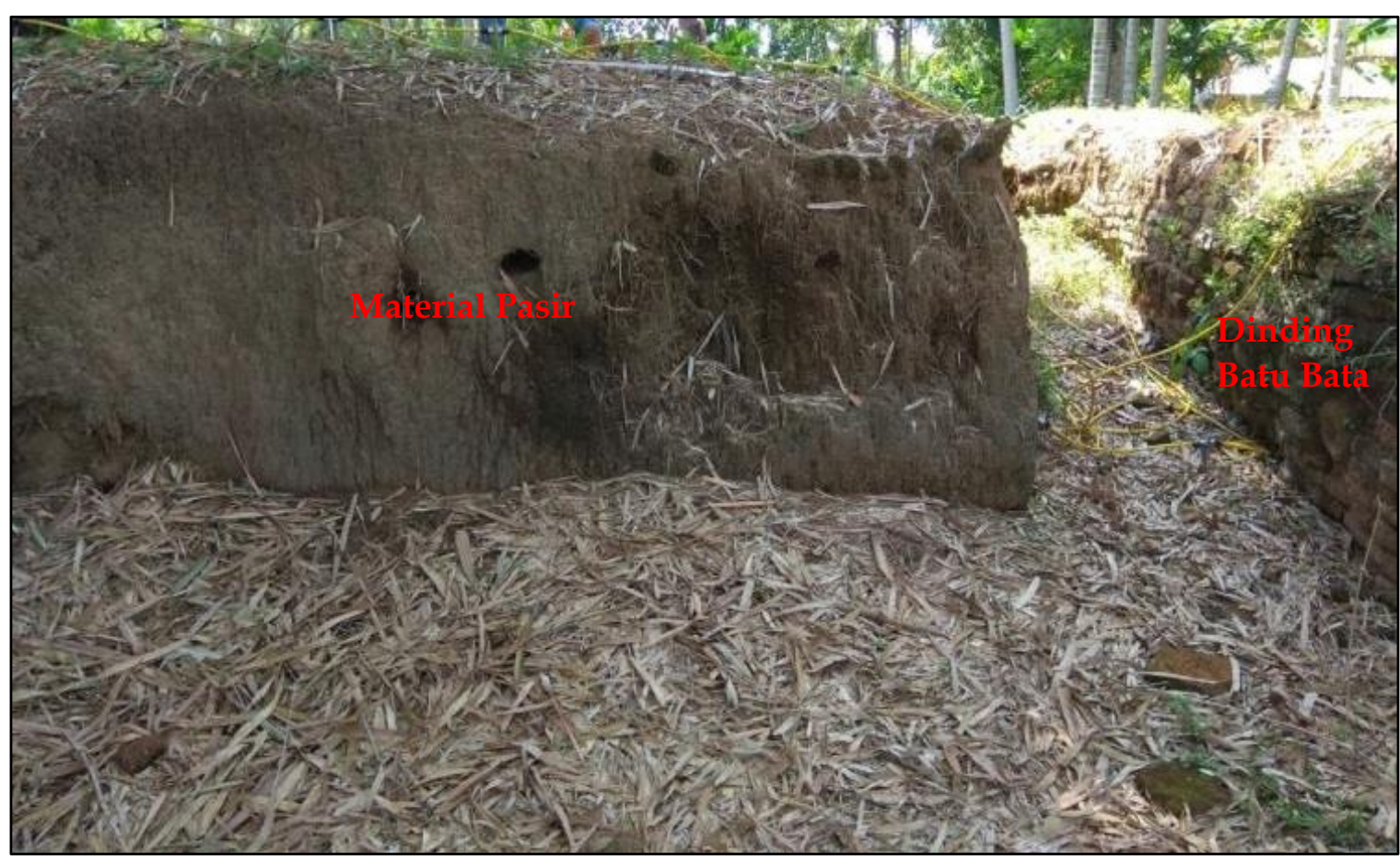

Gambar 2. Singkapan ekskavasi Cot Sidi Abdullah. 
Salah satu metode yang dapat diaplikasikan untuk kajian arkeologi tanpa harus merusak situs dan dapat dijadikan sebagai informasi awal dari keberadaan situs ialah metode geofisika seperti metode magnetik (Alashoo et al, 2011; Mekkawi et al, 2013, Guillaume et al, 2015; Martorana et al, 2017; Welc et al, 2017) dan metode near surface seperti metode geolistrik yang digunakan untuk investigasi keberadaan situs arkeologi di beberapa tempat (Young, dan Droege, 1986; Schmidt, 2009; Karavul et al, 2010; Alashloo et al, 2012), meskipun penggunakannya masih sangat sedikit untuk investigasi situs-situs cagar budaya di Aceh, metode ini cocok digunakan untuk investigasi awal (Persson, 2005). Sebelumnya, Ismail et al (2018) pernah dilakukan kajian arkeologi pada situs CSA dengan menggunakan metode gravity. Penelitian tersebut hanya memetakan sebagian dari keberadaan struktur bangunan situs. Oleh karena itu sangat cocok dilakukan kajian dengan metode geolistrik pada situs CSA untuk memetakan struktur bangunan situs yang telah tertimbun oleh material endapan di bawah permukaan secara keseluruhan, sehingga dapat dijadikan sebagai informasi awal untuk pelestarian dan penyelamatan keberadaan situs CSA bagi intansi-intasi terkait.

\section{METODE PENELITIAN}

Metode geolistrik merupakan metode geofisika yang telah dikembangkan sejak awal tahun 1900-an dan menjadi lebih mudah digunakan sejak tahun 1970-an (Reynolds, 1997). Metode ini dapat memberikan informasi perubahan nilai tahanan jenis bawah permukaan sehingga dapat mengidentifikasikan struktur bawah permukaan (Pryambodo \& Troa, 2016).

Pada penelitian ini, pengukuran metode goelistrik meggunakan konfigurasi Wenner yang dapat memberikan gambaran sensitivitas perubahan listrik secara lateral (Telford et al., 1990). Konfiguras ini menggunakan minimal 2 elektoda arus (AB) dan 2 elektroda potensial (MN) dengan jarak sepertiga (1/3) diantara kedua elektroda yang berada pada satu garis simetris dimana nilai tahanan jenis didapatkan dengan cara dialiri arus listrik searah (DC) ke bawah permukaan melalui 2 buah eletroda arus seperti Gambar 3 yang selanjutnya diterima oleh 2 buah elektroda potensial. Elektroda ini menerima perbedaan nilai potensial yang diakibatkan oleh perbedaan sifat fisis batuan bawah permukaan. Batuan-batuan di bawah permukaan memiliki tingkat kemampuan yang berbeda-beda dalam menghantarkan arus listrik. Besar kecilnya resistivitas batuan menunjukkan kemampuan menghantarkan kuat arus listrik. Semakin tinggi nilai tahanan jenis suatu bahan, semakin sukar bahan tersebut menghantarkan kuat arus listrik (Telford, 1990). Diagram alir penelitian ini dapat dilihat pada Gambar 4.

Pengukuran data geolistrik dilakukan sebanyak 8 lintasan sejajar dengan panjang 41,5 meter dan jarak antar lintasan 5 meter dari arah utara ke selatan situs CSA. Selain itu, juga dilakukan pengukuran satu lintasan dengan panjang 46,5 meter dari arah barat ke timur yang memotong lintasan sejajar dan bangunan situs yang sudah terpendam (Gambar 5). Jarak antar elektroda yang digunakan sebesar 0,5 meter. Hal ini dilakukan untuk mendapatkan hasil dengan resolusi yang tinggi. 


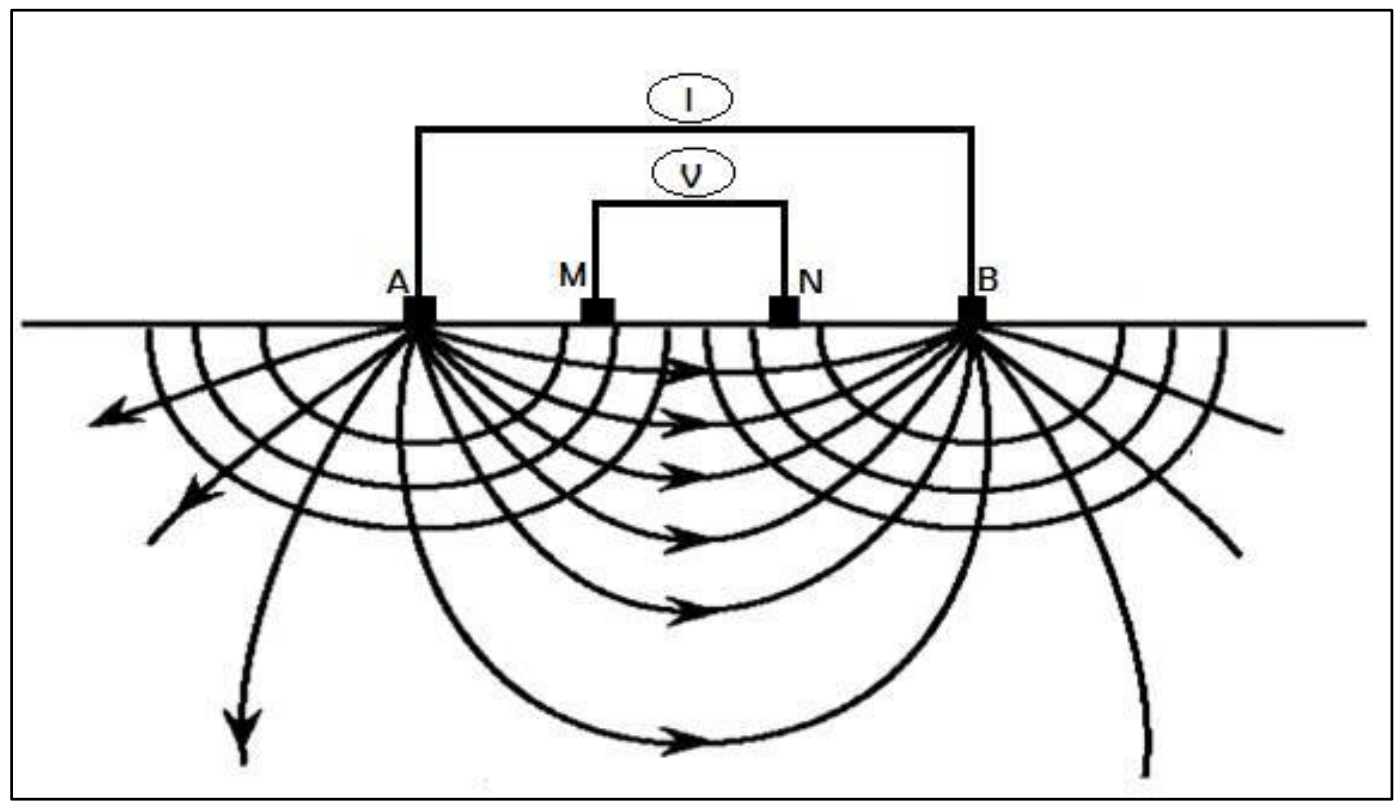

Gambar 3. Prinsip pengukuran metode geolistrik konfigurasi Wenner

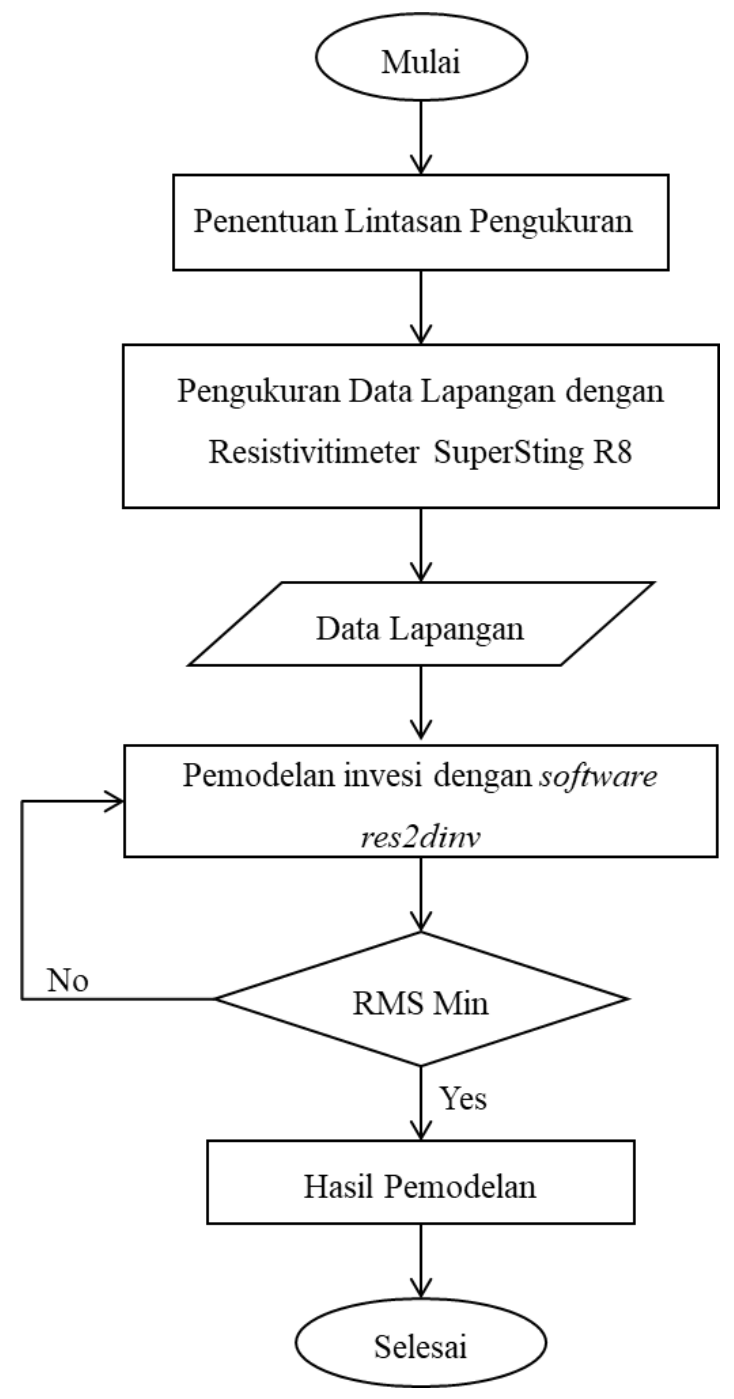

Gambar 4. Diagram Alir Penelitian 


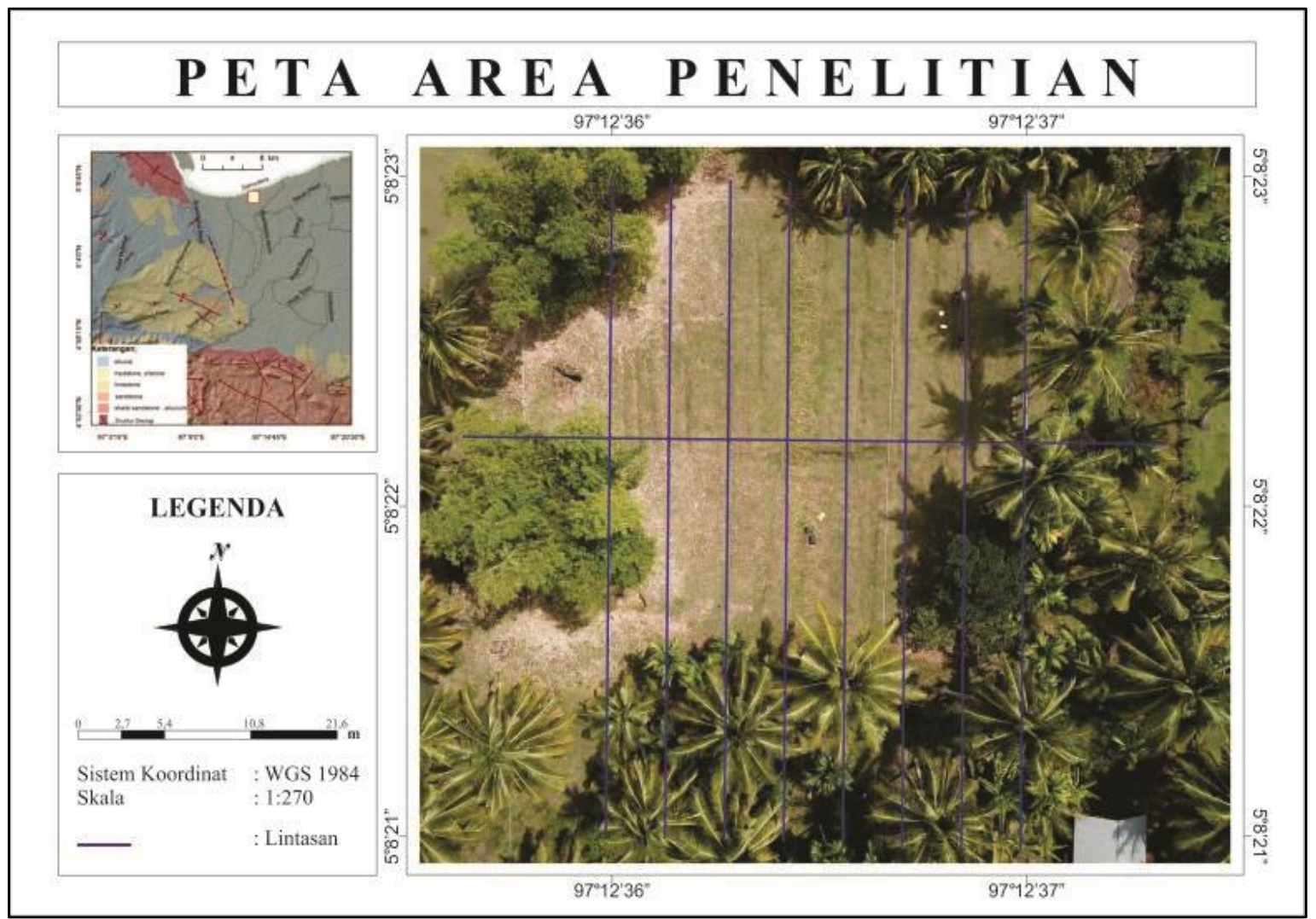

Gambar 5. Area pengukuran data geolistrik

\section{HASIL DAN PEMBAHASAN}

Hasil pengukuran data geolistrik pada situs cagar budaya CSA dengan konfigurasi Wenner didapatkan resistivitas semu (apparent resistivity) untuk masingmasing lintasan (Gambar 6). Nilai resistivitas ini belum mampu menunjukkan keadaan sebenarnya dari objek yang dicari di bawah permukaan, sehingga nilai resistivitas semu ini perlu di modelkan dengan pemodelan inversi (inversi modelling) menggunakan res2dinv yang dikembangkan oleh Loke (2000) untuk memperoleh model 2D dari target di bawah permukaan.

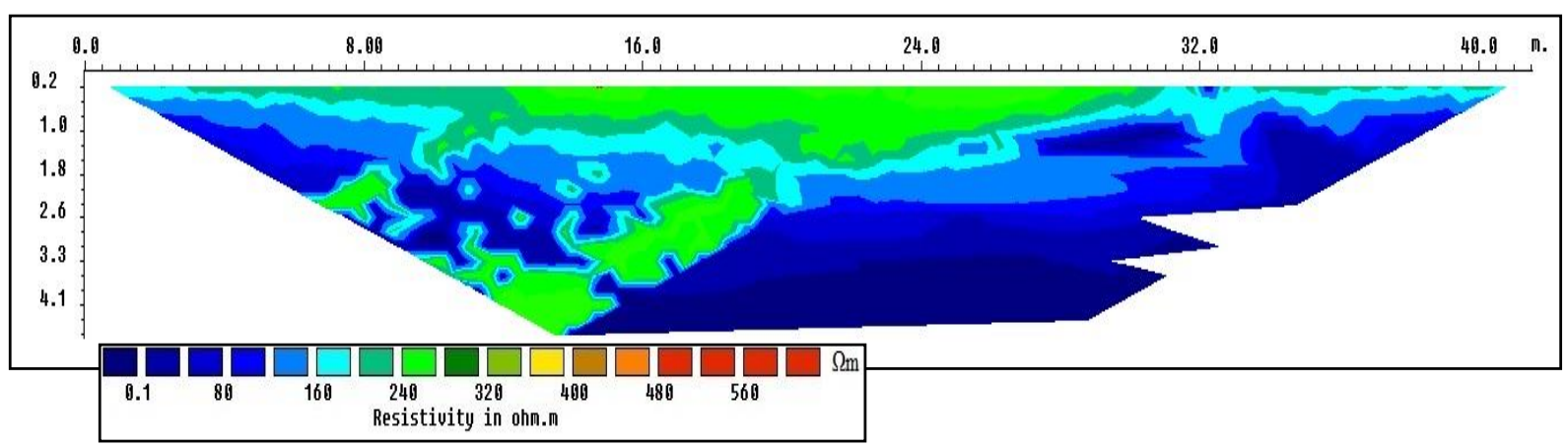

Gambar 6. Model 2D Resistivitas Semu Lintasan 1.

Model penampang resistivitas 2D dari salah satu lintasan pada lokasi pengukuran dapat dilihat pada Gambar 7 . Model ini merupakan hasil model inversi dari lintasan 1 yang dijadikan sebagai acuan dari lintasan-lintasan pengukuran lain pada area situs CSA. Lintasan ini berada pada sisi barat situs CSA yang berjarak \pm 8 meter dengan area tambak dan terdapat beberapa elektroda pengukuran yang tepat berada di 
atas dinding benteng berdasarkan singkapan hasil eskavasi (Gambar 7).

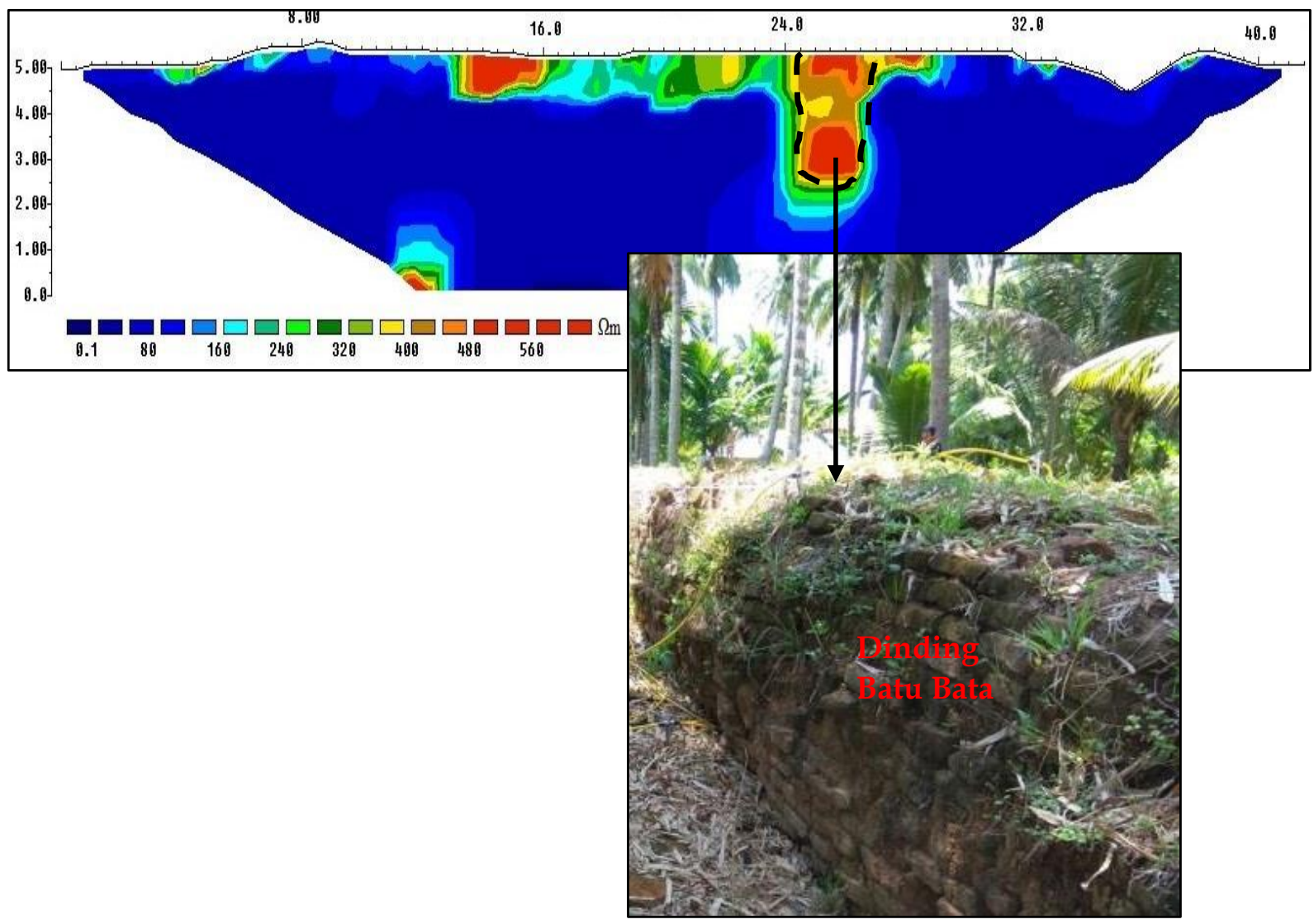

Gambar 7. Model 2D Resistivitas Lintasan 1

Secara keseluruhan Lintasan ini didominasi dimana zona konduktif dengan vasiasi nilai resistivitas $0,1-80 \Omega \mathrm{m}$. Zona ini berada di sebelah utara dan selatan lintasan dengan kedalaman hingga 5 meter. Pada sisi selatan dan utara lintasan dengan jarak bentangan 30 - 41,5 meter dan 0 - 5 meter untuk masing-masing sisi, ini berada di luar area situs. Zona konduktif ini diidentifikasikan berupa pasir intrusi. Selain itu, model resistivitas 2D ini juga menunjukkan adanya zona resistif dengan vasiasi nilai resistivitas $100-600 \Omega$ m yang berada di dekat permukaan. Zona resistif ini berada pada jarak bentangan 13 - 15 meter dan 25-28 meter dengan kedalaman mencapai 1 meter dan 3 meter untuk masing-masing jarak bentangan. Zona resistif ini diidentifikasikan sebagai dinding situs CSA yang terkubur di bawah permukaan sehingga terjadinya penghambatan intrusi air.

Zona resistif dari model 2D resistivitas ini dijadikan sebagai acuan untuk mengidentifikasikan dinding situs yang tertimbun endapan di bawah permukaan pada lintasan-lintasan pengukuran lainnya di situs CSA. Zona resistif ini tepat berada di bawah elektrodaelektroda pengukuran yang ada di atas dinding situs dan diyakini sebagai respon dari dinding situs itu sendiri.

Model 2D resistivitas untuk semua lintasan pengukuran pada area situs CSA dapat dilihat pada Gambar 8a. Gambar 8a ini merupakan penggabungan dari delapan lintasan sejajar dan satu lintasan yang memotong kedelapan lintasan tersebut. Dari 
model 2D resistivitas ini dapat dilihat kontras perbedaan antara zona resistif yang diidentifikasikan sebagai respon area situs dan dari dinding-dinding situs dan zona konduktif yang diidentifikasikan sebagai zona yang terjadi intrusi air dan berada di luar area situs CSA.

Respon dan pola dari model 2D resistivitas semua lintasan (Gambar 8a) dijadikan sebagi acuan menggambarkan kembali struktur dan area situs CSA yang telah terkubur di bawah permukaan (Gambar 8b). Berdasarkan model 2D resistivitas didapatkan bahwa panjang situs CSA \pm 35 meter dan lebar \pm 25 meter yang sudah tertimbun di bawah permukaan. Sehingga perkiraan struktur situs ini dapat dijadikan sebagai pertimbangan untuk merekuntruksi bangunan situs CSA.
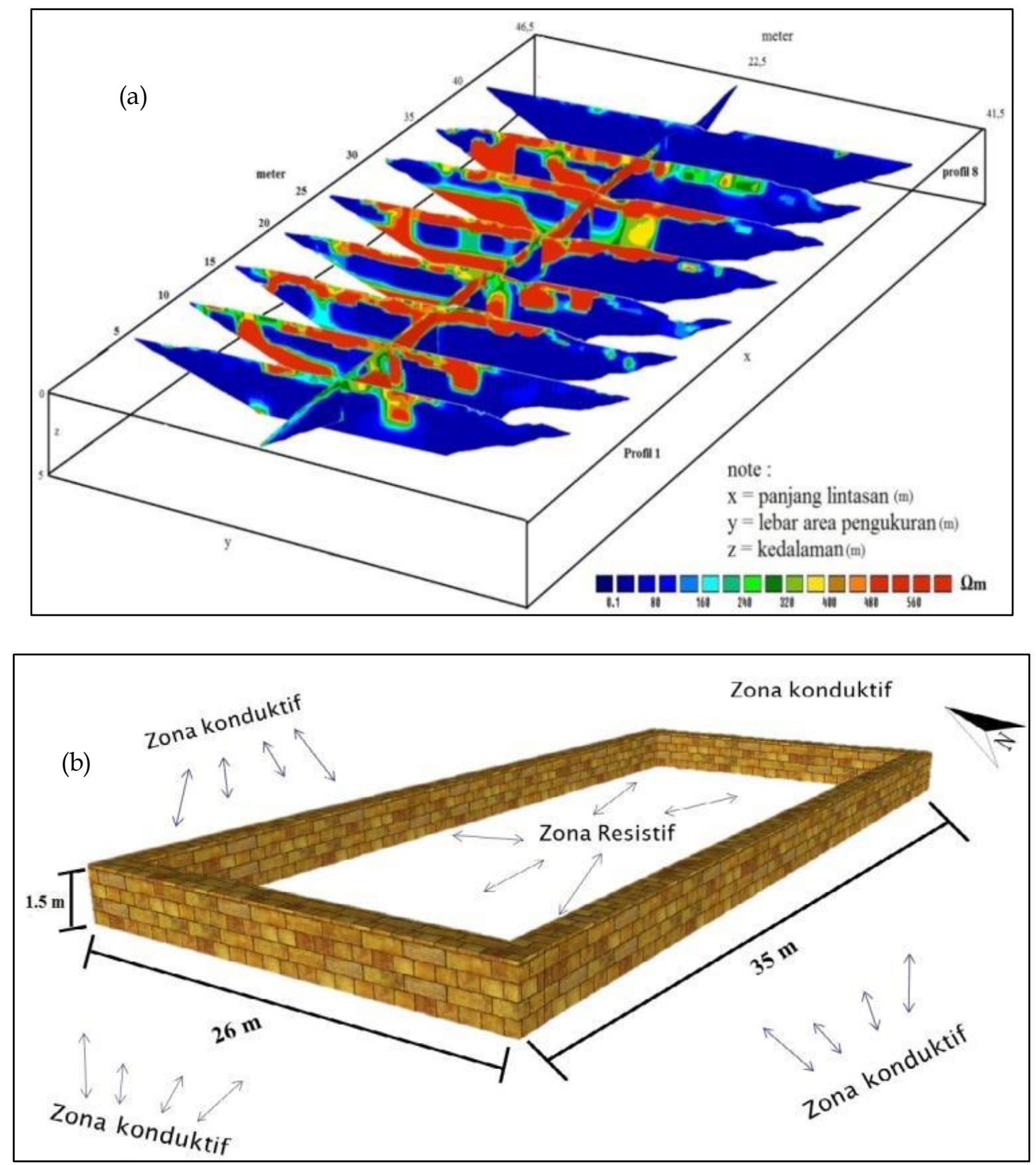

Gambar 8. (a) Model 2D Resistivitas pada semua lintasan, (b) Rekontruksi Bangunan Situs CSA 


\section{KESIMPULAN}

Hasil penelitian menggunakan metode geolistrik konfigurasi wenner di area Situs CSA dapat disimpulkan bahwa di daerah penelitian didominasi oleh pasir terintrusi dengan variasi nilai resistivitas 0,1 - $80 \Omega$ m yang berada di area luar situs, dan pasir tak terintrusi dengan variasi nilai resistivitas 100 - $560 \Omega \mathrm{m}$ yang berada di dalam Situs CSA. Tingginya nilai resistivitas ini juga dipengaruh oleh dinding-dinding situs yang tersusun dari batu bata buatan manusia.

Berdasarkan model, hasil interpretasi, dan bukti fisik di area pengukuran, bangunan Situs Cot Sidi Abdullah mempunyai bentuk seperti persegi panjang dengan panjang bangunan 35 meter, lebar 25 meter, dan memliki ketebalan dinding situs 1,5 meter.

\section{UCAPAN TERIMA KASIH}

Peneliti menyampaikan ucapan terimaksih kepada Kementrian Riset, Teknologi, dan Pendidikan Tinggi (Kemenristekdikti) yang telah membiayai penelitian ini melalui skim Penelitian Berbasis Kompetensi dan kawan-kawan yang telah banyak membantu untuk pengukuran data.

\section{DAFTAR PUSTAKA}

Alashloo, S. M., Saad, R., Nawawi, M. N. M., Saidin, M., \& Alashloo, M. M. (2011). Magnetic and 2D electrical imaging methods to investigate an archaeological site at Sungai Batu, Kedah, Malaysia. In 3rd International Conference on Chemical, Biological and Environmental Engineering, IPCBEE (Vol. 20).

Bennet, J., Bridge, D., Cameron, N., Djunuddin, A., Ghazali, S., Jeffery, D., ... \& Whandoyo, R. (1981). Peta Geologi Lembar Banda Aceh. Sumatra Skala, 1(250.000).

BPCB Aceh. (2014). Ekskavasi Penyelamatan Struktur Cagar Budaya Cot Sidi Abdullah. Laporan Kegiatan. Aceh
Besar. Balai Pelestarian Cagar Budaya Aceh.

Guillaume, B., Francois, L., Vivien, M., Adrien, C., Carole, R., \& Ard Vincent. (2015). High spatial resolution magnetic survey on the Neolithic site of Le Pontet (Charente-Maritime, France): presentation of the method and associated processing. International Conference on Metrology for Archaeology Benevento, Italy. https://scanr.enseignementsuprecherche.gouv.fr/publication/hal01520765

Ismail, N., Yanis, M., Abdullah, F., Irfansyam, A., \& Atmojo, B.S.W. (2018). Mapping buried ancient structure using gravity method: A case study from Cot Sidi Abdullah, North Aceh. Jorunal of Physics: Conference Series, 1120 (1), 1-5. https://iopscience.iop.org/article/10.1 088/1742-6596/1120/1/012035.

Karavul, C., Dedebali, Z., Keskinsezer, A., Beyhan, G., \& Demirkol, A. (2010). Magnetic and electrical resistivity image survey in a buried Adramytteion ancient city in Western Anatolia, Turkey. International Journal of the Physical Sciences Vol. 5(6), page 876-883. https:/ / academicjournals.org/journal/ IJPS/article-abstract/947362227302.

Loke, M. (2000). Time-Lapse Resistivity Imaging Inversion. Proceedings of the 5 th Meeting of the Environmental and Engineering Geophysical Society European Section, Budapest, Hungary. https://doi.org/10.3997/22144609.201406397.

Martorana, R., Capizzi, P., Alessandro, A., Pisciott, A., \& Scudero. (2017). GPR and Magnetic Survey at the Kamarina Archaeological Site (Sicily, Italy) Supported by Aerial Photograpic and Thermographic Data.

GNGTS. https://iris.unipa.it/handle/10447/24 5790\#.Xk4fYSgzbIV

Mekkawi, M., Hamed, T.A., \& Abdellatief, T. (2013). Detailed magnetic survey at Dahshour archeological sites Southwest Cairo, Egypt. NRIAG Journal of Astronomy and Geophysics, Vol. 2, Page

175-183. 
https://doi.org/10.1016/j.nrjag.2013.06 .020 .

Moquette, J. P. (1913). De eerste vorsten van Samoedra-Pase (Noord Sumatra). Rapport voor Oudheidkunding Dients.

Persson, K. (2005). Integrated geophysicalgeochemical methods for archaeological prospecting. $\mathrm{KTH}$, Land and Water Resources Engineering. https://www.semanticscholar.org/pap er/Integrated-geophysicalgeochemical-methods-forPersson/c284f9358f3269620763212d25c 5020db81d2731.

Pryambodo, D.G., \& Troa, R.A. (2016). Aplikasi Metode Geolistrik untuk Identifikasi Situs Arkeologi di Pulau Laut, Natuna. KALPATARU, Majalah Arkeologi Vol. 2, No. 1, hal. 45-52. http://dx.doi.org/10.24832/kpt.v25i1. 82.

Reynolds, J.M. (1997). An Introduction to Aplied and Eviromental Geophysics. Jhon Wiley \& Sons. England.

Schmidt, A. (2009). Electrical and Magnetic Methods in Archaeological Prospection. Seeing the Unseen. Geophysics and Landscape Archaeology, page 67-81. http://dx.doi.org/10.1201/9780203889 558.pt2
Sumarsih, S. (1985), Risalah Sejarah dan Budaya, Seri Terjemahan Naskah Kuno, Departemen Pendidikan dan Kebudayaan, Direktorat Jendral Kebudayaan, Balai Kajian Sejarah dan Nilai Tradisional. Yogyakarta.

Telford, W. M., Geldart, L. P., \& Sheriff, R. E. (1990). Applied Geophysics Second Edition, Cambridge University Press, USA.

Welc, F., Mieszkowski, R., Vrkljan, G.L., \& Konestra, A. (2017). An Attempt to Investigation of Different Geophysical Methods (Magnetic, GPR, and ERT); A case Study from The Late Roman Sttlement on The Island of Rab in Croation. Studia Quaternaria, vol. 34, no.1:47-59. http://dx.doi.org/10.1515/squa-20170004.

Young, C.T., \& Droege, D.R. (1985). Archaeological applications of resistivity and magnetic methods at Fort Wilkins State Park, Michigan. Geophysics, Vol. 51. No. 3, Page 568-575.

https://doi.org/10.1190/1.1442111 